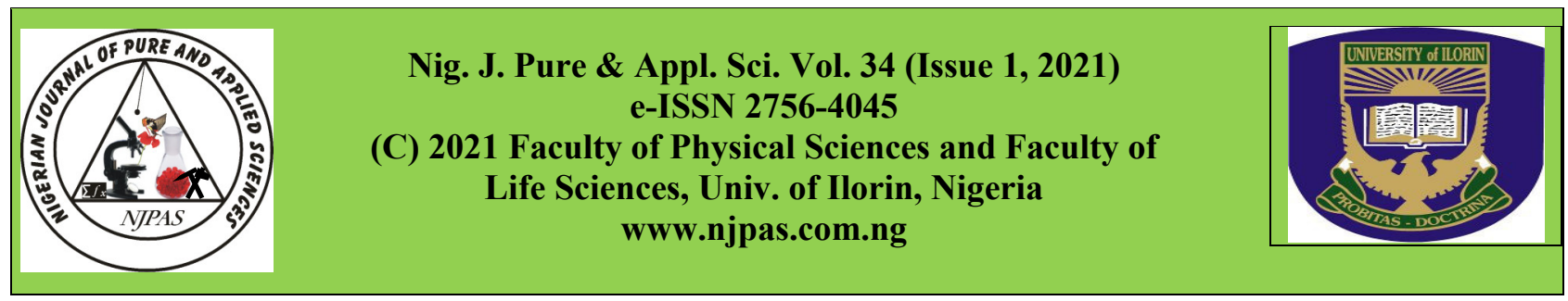

http://dx.doi.org/10.48198/NJPAS/20.B14

\title{
Avian Frugivores Fruit Choice in the Forest Patch of Federal College of Forestry Jos, Plateau State Nigeria
}

Page | 3874

Francis M. Junior, Kambai Collina, Chomini M. Stephen, Nanlir Janfa and Kabeer Sani

Department of Forestry Technology Federal College of Forestry Jos, P.M.B. 2019 Jos

\section{ABSTRACT}

The flora community which attract a different frugivores may be important to the survival of such frugivores. Relationship between avian biodiversity and fruit producing plants may reflect avian fruit choice or preference. This research was done on avian frugivores fruit choice within the forest cover of Federal College of Forestry, Jos in order to study the species and their activity on fruit-producing plants in the site and to compare encounter rate and diversity of avian frugivores across habitats. Bird species were estimated and 212 individual fruit-eating avian species were counted on 28 species of fruit producing plants during this survey. Mean number of fruiteating birds did not differ significantly in the habitats ( $\mathrm{F} 63=0.1245$, Adjusted $\mathrm{R} 2=-0.02769, \mathrm{P}=0.8832)$. The abundance of birds in relation to plant species showed a very high significant difference $(2=339.55, \mathrm{df}=27, \mathrm{P}$ $<0.001)$. Shannon weiner diversity of birds calculated showed that the diversity in relation to habitat types showed no significant difference $\left(\chi^{2}=0.045285, \mathrm{df}=2, \mathrm{P}=0.9776\right)$. This habitat should therefore be seen as an important habitat for birds and other wildlife.

Keywords: Avian frugivores, Diversity, Forest patch, Fruit choice, Habitat types

\section{Introduction}

Higher plants are a major diet for frugivores especially the avian species in a typical ecosystem (Walker 2007; Jordano 2014; Daru et al., 2015). Such fruit producing trees are therefore seen as an important resource which is sometimes marked and defended by avian species that utilize them. Birds are a key component of all ecosystems playing important ecological roles in seed dispersal which can contribute to the maintenance of species diversity (Snow 1981; Wenny and Levey 1998 Holbrook and Smith 2000; Peh and Chong 2003). Fruit producing trees such as the figs for example are well known as a key component of fruit resources in tropical forests (Lamberts and Marshall, 1991; Shanaban et al., 2003). Frugivory is a central and important process in plant populations where natural regeneration is strongly dependent upon animal-mediated seed dispersal (Jordano, 2014).

It is widely believed that foraging animals do not possess the sensory equipment to discriminate precisely among prey of varying profitability and to overcome this problem, animals must make foraging decisions using alternative mechanism

Corresponding Author: Francis, Mundi Junior

Department of Forestry Technology Federal College of Forestry Jos, P.M.B. 2019 Jos

Email:mundi francis@yahoo.com 
which are in most cases correlated with profitability (Sallbanks, 1993).

This research was out to determine the fruit choice or preference by avian species in the forest patch of Federal College of Forestry Jos, Plateau State Page | 3875 Nigeria.

\section{Materials and Methods \\ Study Area}

The study was conducted in Federal College of Forestry Jos located on latitude $09^{\circ} 57^{\prime} \mathrm{N}$ and longitude $08^{\circ} 54^{\prime} \mathrm{E}$ and elevation of $1180 \mathrm{~m}$ above Sea level with mean annual rainfall of about 1250mm (Francis et al., 2017). Three habitat types were categorized, for this research namely; riparian forest, farmland and orchard. Orchard represented an area within the research area where fruit trees are predominantly found being planted some years ago. Farmland represented an area within the research location that serves as a site for planting and other agricultural activities. Riparian forest represented the forest within the study area with a flowing stream. Some major species of plants in the College are Tectona grandis, Eucalyptus camaldulensis, Gmelina arborea, Delonix regia, Terminalia catapa, Stenolobium stans, Spathodea campanulata, Corymbia torelliana, Psidium guajava, Phallantas mellerianus, Bauhinia vahlii, Thevetia peruviana, Khaya senegalensis, Ceiba pentandra, Nauclea latifolia, Giricidium sepium, Mangifera indica, Citrus sp, Erythrophleum suaveolens etc (Francis et al., 2017).

\section{Data collection}

Line transects and point count was used for the survey of the frugivorous birds (Bibby et al., 2000, Yellop et al., 2003). A total of 9 transects each of $200 \mathrm{~m}$ were placed by stratified random sampling in the habitat types totaling 27 and subdivided in to $100 \mathrm{~m}$ sections each. The start and the end point of each transects were marked with a Global Positioning System (GPS MAP 60). Frugivorous birds were observed in a point count using a pair of binoculars (Trekka, magnification-10×42) from 6:00am to 10:30am for the period of 90 days. Birds were identified with the aid of field guide of birds of Western Africa (Borrow and Deymey, 2004). Point count and opportunities sightings along the $200 \mathrm{~m}$ transect were done. Birds carrying out the act of frugivory were carefully observed for a maximum of 5minutes. The plants visited by avian species were identified using Field Keys by Hopkins and Stand field (1996) with the assistance of a trained taxonomist.

\section{Statistical Analysis}

Data obtained were analyzed using $\mathrm{R}$ Console software (Version 3.2.2). Abundance of birds in relation to plant species was compared using Pearson's Chi-square test. One-way analysis of variance (ANOVA) was used to compare the mean abundance of birds in relation to habitat types. Pearson's Chi-square test was used to compare diversity index of birds across habitat types. The Pvalues $<0.05$ were considered statistically significant.

\section{Results}

A total of 212 individual frugivorous birds were recorded on 28 species of fruits producing plants during this survey (Table 1).

\section{Comparison of frugivorous bird's abundance in relation to habitat types}

Frugivorous birds were encountered in all the habitat types during this study. Therefore, the mean abundance of the birds in relation to habitat types showed no significant difference $\left(\mathrm{F}_{63}=0.1245\right.$, Adjusted $\mathrm{R}^{2}=-0.02769, \mathrm{P}=0.8832$, Figure 1). Even though statistically, there was no significant difference in the abundance of the frugivorous birds across habitats, but from the bar plots in figure1, more frugivorous avian species were seen in the Riparian forest followed by the Orchard and then Farmland. 


\section{Comparison of bird's abundance in relation to} plant species

Corymbia torelliana had the highest number of frugivores visit, followed by Ficus species, Eucalyptus camaldulensis, Vitex doniana and Page | 3876 Anacardium occidentale. Others had low visit (Table1). Therefore, the abundance of birds in relation to plant species for the Chi square showed a very high significant difference $\left(\chi^{2}=339.55, \mathrm{df}=\right.$ $27, \mathrm{P}<0.001)$.

\section{Diversity index of birds in relation to habitat types}

Shannon weiner diversity of birds calculated showed that the diversity in relation to habitat types showed no significant difference $\left(\chi^{2}=0.045285\right.$, df $=2, \mathrm{P}=0.9776)$. Avian frugivorous species were more diverse in the riparian forest followed by the orchards and then the farmland, even though the Shannon-weiner diversity index for the three habitats was less than 2.4 suggesting low diversity (Lameed, 2011; Francis et al., 2017).

Table 1: Demographic information of the selected subjects, the Mean \pm SD and range

\begin{tabular}{|c|c|c|c|c|}
\hline \multirow[t]{2}{*}{ Species } & \multicolumn{3}{|c|}{ Habitat types } & \multirow[t]{2}{*}{ Birds abundance } \\
\hline & Farmland & Orchard & $\begin{array}{c}\text { Riparian } \\
\text { forest }\end{array}$ & \\
\hline Albizia lebbeck & & $\sqrt{ }$ & & 2 \\
\hline Anacardium occidentale & $\sqrt{ }$ & $\sqrt{ }$ & & 14 \\
\hline Annona senegalensis & & $\sqrt{ }$ & & 2 \\
\hline Calusena anisate & $\sqrt{ }$ & & & 2 \\
\hline Canarium schweinfurthii & $\sqrt{ }$ & & & 5 \\
\hline Combretum nigricans & $\sqrt{ }$ & & & 2 \\
\hline Corymbia torelliana & $\sqrt{ }$ & $\sqrt{ }$ & $\sqrt{ }$ & 43 \\
\hline Eucalyptus camaldulensis & $\sqrt{ }$ & $\sqrt{ }$ & $\sqrt{ }$ & 26 \\
\hline Ficus cordata & $\sqrt{ }$ & $\sqrt{ }$ & & 10 \\
\hline Ficus glumosa & $\sqrt{ }$ & $\sqrt{ }$ & & 27 \\
\hline Ficus ingens & & & $\sqrt{ }$ & 10 \\
\hline Ficus platyphyla & & & $\sqrt{ }$ & 2 \\
\hline Ceiba petendra & & & $\sqrt{ }$ & 1 \\
\hline Gmelina arborea & $\sqrt{ }$ & $\sqrt{ }$ & & 5 \\
\hline Isoberlina doka & $\sqrt{ }$ & & & 2 \\
\hline Mangifera indica & $\sqrt{ }$ & $\sqrt{ }$ & & 5 \\
\hline Nauclea latifolia & & $\sqrt{ }$ & & 1 \\
\hline Phoenix dactylifera & & & $\sqrt{ }$ & 2 \\
\hline Phoenix reclinata & & & $\sqrt{ }$ & 5 \\
\hline Senna siamea & & & $\sqrt{ }$ & 3 \\
\hline Senna singueana & & & $\sqrt{ }$ & 1 \\
\hline Spathodea campanulata & & $\sqrt{ }$ & & 5 \\
\hline Syzgium guineense & & & $\sqrt{ }$ & 5 \\
\hline Terminalia curatelliforlia & $\sqrt{ }$ & & & 3 \\
\hline Terminalia macroptara & $\sqrt{ }$ & & & 3 \\
\hline Trema orientalis & & & & 11 \\
\hline Uapaca spp. & & & & 1 \\
\hline Vitex doniana & & & & 14 \\
\hline \multirow[t]{3}{*}{ Number of birds } & 46 & 65 & $\begin{array}{c}101 \\
\sqrt{ }\end{array}$ & 212 \\
\hline & & $\sqrt{ }$ & & \\
\hline & & $\sqrt{ }$ & $\sqrt{ }$ & \\
\hline
\end{tabular}

$\sqrt{ }$ : Plant species present 
Table 2: Shannon-Weiner diversity index of frugivorous birds in Orchards

\begin{tabular}{lllll}
\hline Species & Number & $\mathbf{P i}$ & $\mathbf{I n}(\mathbf{P i})$ & $\mathbf{P i}[\mathbf{l n}(\mathbf{P i})]$ \\
\hline Common bulbul & 20 & 0.307692 & -1.17865 & -0.36266 \\
Laughing dove & 2 & 0.030769 & -3.48124 & -0.10712 \\
Senegal parrot & 8 & 0.123077 & -2.09495 & -0.25784 \\
Speckled mouse bird & 6 & 0.092308 & -2.38263 & -0.21993 \\
Western grey plantain eater & 29 & 0.446154 & -0.80709 & -0.36009 \\
Total & 65 & & & -1.30764 \\
$\mathrm{H}^{\prime}=-(-1.307639)$ & & & & \\
$\mathrm{H}^{\prime}=+1.307639$ & & & & \\
\hline
\end{tabular}

Table 3: Shannon-Weiner diversity index of frugivorous birds in Riparian Forest

\begin{tabular}{lllll}
\hline Species & Number & $\mathbf{P i}$ & $\ln (\mathbf{P i})$ & $\mathbf{P i}[\ln (\mathbf{P i})]$ \\
\hline Bruce's green pigeon & 5 & 0.049505 & -3.0056826 & -0.1488 \\
Common bulbul & 37 & 0.366337 & -1.0042026 & -0.36788 \\
Common white eye & 8 & 0.079208 & -2.535679 & -0.20085 \\
Laughing dove & 1 & 0.009901 & -4.6151205 & -0.04569 \\
Senegal parrot & 8 & 0.079208 & -2.535679 & -0.20085 \\
Speckled mouse & 25 & 0.247525 & -1.3962447 & -0.34561 \\
Violet turaco & 2 & 0.019802 & -3.9219733 & -0.07766 \\
Western grey plantain eater & 15 & 0.148515 & -1.9070703 & -0.28323 \\
\hline Total & $\mathbf{1 0 1}$ & & & $\mathbf{- 1 . 6 7 0 5 5}$ \\
\hline
\end{tabular}

$\mathrm{H}^{\prime}=-(-1.67055)$

$\mathbf{H}^{\prime}=+\mathbf{1 . 6 7 0 5 5}$

Table 4: Shannon-Weiner diversity index of frugivorous birds in Farmland

\begin{tabular}{lllll}
\hline Species & Number & $\mathbf{P i}$ & $\mathbf{I n}(\mathbf{P i})$ & $\mathbf{P i}[\mathbf{l n}(\mathbf{P i})]$ \\
\hline African thrush & 3 & 0.06522 & -2.73 & -0.178 \\
Common bulbul & 16 & 0.34783 & -1.0561 & -0.3673 \\
Senegal parrot & 4 & 0.08696 & -2.4423 & -0.2124 \\
Speckled mouse bird & 12 & 0.26087 & -1.3437 & -0.3505 \\
Western grey plantain eater & 11 & 0.23913 & -1.4307 & -0.3421 \\
\hline Total & $\mathbf{4 6}$ & & & $\mathbf{- 1 . 4 5 0 4}$ \\
\hline $\mathrm{H}^{\prime}=-(-1.45042)$ & & & & \\
$\mathbf{H}^{\prime}=+\mathbf{1 . 4 5 0 4 2}$ & & & &
\end{tabular}




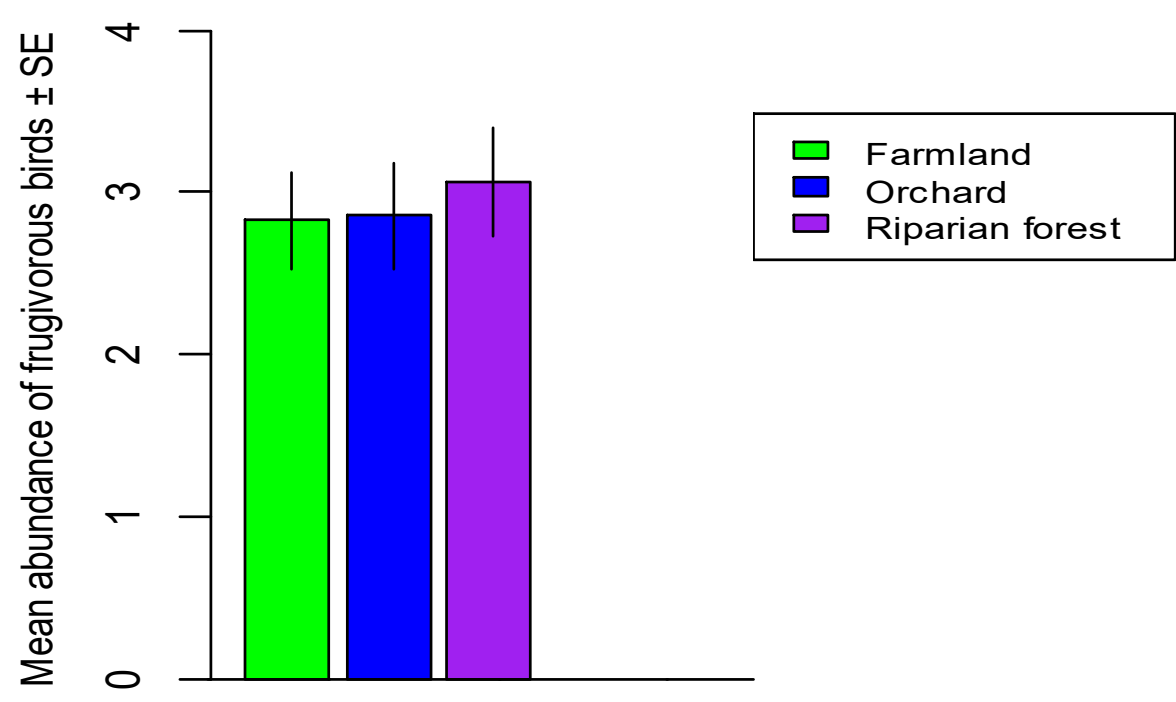

Habitat types

Figure 1: The mean abundance of frugivorous birds in relation to habitat types

\section{Discussion}

The total number of frugivorous bird species recorded on the plant species shows that availability of fruits especially the ones recorded during the survey is a key factor influencing the abundance and the diversity of the birds. It also shows that the area is a repository for not only avian species but for biodiversity as a whole. The mean abundance of frugivorous birds in relation to habitat types showed no significant difference. Majority of the birds such as Common bulbul, laughing dove, Speckled mouse bird, Western grey plantain eater and Senegal parrot were among the major frugivorous species and were recorded in all the habitat types. They were probably attracted to fruits irrespective of the habitat types the fruit plant grows. Burgess et al., 2002 showed that certain species of birds can occupy or utilize more than one habitat types as long as the habitat provides their basic resource requirements.

\section{Comparison of Birds Abundance in Relation to Plant species}

The abundance of birds in relation to plant species showed a very high significant difference. Majority of the frugivorous avian species were observed to utilize Corymbia torelliana, ficus spp, Eucalyptus camaldulensis, Terminalia spp and Vitex doniana. Francis et al., 2017 had documented these plants to be some of the most abundant species in the forest cover of the college. What attracted the birds was not the abundance of the plant species but the fruits of the plants. Corymbia torelliana was the most visited fruit producing plant and it was recorded in the three habitat types. Eucalyptus camaldulensis also occurred in the three habitat types. All the plants that occurred in the three habitat types recorded the highest number of foraging visitors, therefore habitat type was not basically necessary but fruit resource played a major role in attracting frugivorous species. Ficus species were also 
important food for the Bruce's green Pigeon. Barde and Abiem (2015) had reported Ficus species to have a wide range of distribution and uses. It is an important diet for birds. This is similar to the findings of Morel et al. (1986)

Page | 3879 where differential attractiveness of Ficus species has previously been reported for African fruiteating birds such as the Bruce's green pigeon. These birds according to morel et al. were more attracted to Ficus platypylla. Daru et al. (2015) in their study on birds use of Ficus species in Amurum forest Reserve Nigeria reported that frugivorous species such as Bruce's green pigeon fed almost extensively on Ficus lutea. It has been reported that plant species that attract a different community of frugivorous avian species may as well be important for the survival of the birds (Peres, 2000). The relationships observed in our study between the birds and the fruit producing trees may reflect avian fruit choice or preference for example, Bruce's green pigeon was attracted to Ficus cordata where the birds were observed to feed extensively on the fruit for more than five minutes during the focal observation compared to other fruits.

\section{Diversity Index of Birds in Relation to Habitat Types}

The diversity of birds in the habitats did not differ significantly. The study showed that the value of Shannon-weiner diversity index for frugivores in the three habitat types was lower than 2.4 implying low diversity. Diversity index ranges from 0-5. 0-2.4 shows low diversity while 2.5-5.0 shows high diversity.

Though the three habitats showed low diversity of frugivores, the Riparian Forest had the highest diversity of such feeding guild $(\mathrm{H}=1.6)$, followed by the Orchard $(\mathrm{H}=1.4)$ and then the Farmland $(\mathrm{H}=1.3)$.

\section{Conclusions}

This result shows that the habitats in the study site can still serve as a habitat to a host of biodiversity which in turn calls for effective management and protection.

\section{Competing interests}

Authors have declared that no competing interests exist.

\section{References}

Barde, E.E. and Abiem, I. (2015). Assessment of Ficusluthea. Diversity in Amurum forest reserve in Jos Plateau State, Nigeria. Journal of Environmental Sciences, Toxiocology and Food Technology, 9; 5662.

Bibby, C.J., Burgess, N.D. and Hill, D.A. (2000). Bird census Techniques. Academic press London. Pp. 302.

Borrow, N. and Demey, R. (2004). Field Guide to the Birds of Western Africa. A \& C Black Publishers Ltd. Pp. 510.

Burgess, N.D., Doggard, N and Lovett, J. (2002). The Uluguru Mountains of Eastern Tanzania: the effect of forest loss on biodiversity. Oryx, 36;140-152.

Daru, B.H., Yessoufou, K., Nuttman, C. and Abalaka, J. (2015). A preliminary study of birds use of fig Ficus species in Amurum forest reserve, Nigeria. Malimbus, 37; 1-15.

Francis, M.J., Dami, F.D., Kambai, C. and Habila, M.A. (2017). Birds species abundance, richness and diversity in Federal College of Forestry Jos, Plateau State, Nigeria. African Journal of Natural Sciences, 20;21-32.

Hopkins, B. and Stanfield, D.P. (1996). A field key to the savanna trees of Nigeria. Ibadan University Press, Nigeria. Pp 1- 31.

Holbrook, K.M. and Smith, T.B. (2000). Seed dispersal and movement patterns in two 
species of Ceratogymma hornbills in a West African tropical lowland Forest. Oecologia, $125 ; 249-257$.

Jornano, P. (2014). Fruits and Frugivory. The ecology of Regeneration in plant Communities, $3^{\text {rd }}$ Edition (ed.R.S. Gallagher). Pp. 1-62.

Lambert, F.R. and Marshall, A.G. (1991). Keystone characteristics of bird-dispersed Ficus in a Malaysian Lowland Rainforest. Journal of Ecology, 79; 793-809.

Lameed, G.A. (2011). Species diversity and abundance of wild birds in Dagona Waterfall Sanctuary Borno State, Nigeria. African Journal of Environmental Science and Technology, 5; 855-866.

Peh, K.S.H. and Chong, F.L. (2003). Seed dispersal agents of two Ficus species in a disturbed tropical Forest. Ornithological Science, 2; 119-125.

Morel, G.J., Morel, M.Y. and Fry, C.H. (19867). Columbidae, Pigeons and Doves. Pp 442497 in Urban, E.K., Fry, C.H. and Keith, S. (eds). The Birds of Africa, vol.2. Academic press, London.

Peres, C.A. (2000). Identifying keystone plant resources in the tropical forest: the case of gums from Parkia pods. Journal of Tropical Ecology, 16; 287-317.

Sallbanks, R. (1993). Hierarchical mechanisms of fruit selection by an avian frugivore. Ecology, 74 (5); 1326-1336.

Shanaham, M., So, S., Compton, S.G. and Corlett, R. (2003). Fig-eating by Vertebrate Frugivores: a global review. Biol. Rev,76; 529-572.

Snow, D.W. (1981). Tropical Frugivorous birds and their food plants: a world survey. Biotropica, 13; 1-14.

Walker, J.S. (2007). Diatery specialization and fruit availability among Frugivorous birds on Sulawesi. Ibis, 149;345-356.

Wenny, D.G. and Levey, D.J. (1998). Directed seed dispersal by bellbirds in a tropical cloud forest. Proc. Natl. Acad. Sci., U.S.A. 95; 6204-6207.

Yallop, M.L., Connell, M.J. and Bullock, R. (2003). Water birds: Herbivory on a newly created Wetland complex: potential implication for site management and habitat creation. Wetland Ecology and Management, 12; 395-408. 